\title{
Optics in the physics degree at the USC: the use of the Moodle platform
}

\section{Teresa Flores-Arias}

M. Teresa Flores-Arias, "Optics in the physics degree at the USC: the use of the Moodle platform," Proc. SPIE 9289, 12th Education and Training in Optics and Photonics Conference, 92891Y (17 July 2014); doi: 10.1117/12.2070759

SPIE Event: 12th Education and Training in Optics and Photonics Conference, 2013, Porto, Portugal 


\title{
Optics in the Physics Degree at the USC: The use of the Moodle platform
}

\author{
M.Teresa Flores Arias* \\ Grupo de Microóptica y Óptica GRIN, Facultade de Física y Facultade de Óptica y Optometría, \\ Universidade de Santiago de Compostela, Campus Vida s/n 15782, Santiago de Compostela, Spain
}

\begin{abstract}
The unification of the new European studies under the Bologna process creates a new adaptation within the field of Physics. An adjustment to the programs is required to migrate to the new European Credit Transfer (ECTS). According to the article 12.2 of the R.D. 1393/2007, the Physics Degree at the University of Santiago de Compostela (USC), Spain, has 240 ECTS distributed in 4 years with 60 ECTS each. In particular, the subject of Optics is imparted in the third year of the degree and it is divided in two courses, Optics I and Optics II, both belonging to the Module "Fundamentals of Physics". Both courses are mandatory and are composed by 6 ECTS, distributed in 30 hours of theory, 15 hours of seminars and 15 hours of particular tutorials. Besides, the work developed by the students is supposed to be 75 hours of dedication for learning the theoretical lectures contents and 15 hours for the development of exercises and other homework.

The reduction of the number of hours devoted to the theoretical lesson respect to the older syllabus has made necessary the use of virtual platforms for helping the teacher and the student to be more connected and to share the academic materials needed to the good developing of the course. This work is devoted to the analysis of this kind of virtual tools, in particular, to the Moodle platform, in the course Optics I, focusing on the satisfaction degree of the student with it.
\end{abstract}

Keywords: Optics in Physics Degree, USC, online platform, EHEA, Moodle.

\section{INTRODUCTION}

In the year 1999 starts the construction of the European Higher Education Area (EHEA), with the signing of the Bologna Declaration. The convergence of higher education institutions in this space sponsored by the European Union, involves the approval of universitary studies in Europe and the creation of an open space for students, faculty, staff and university administration. In the ministerial meetings hold in Prague (2001), Berlin (2003), Bergen (2005), London (2007), and Leuven(2009), the progress of the process were assessing and new goals were marked.

This process was completed in 2010 entailed a number of legal and institutional changes, in Spain, that are being discussed and specifying. The new degree structure (Royal Decree 1393/2007, October 29 ${ }^{\text {th }}$, in establishing the new system of management of official teachings), the ECTS credit system (Royal Decree $1125 / 2003$, $5^{\text {th }}$ September , by establishing the European credit system and the qualification system in the official university degrees and valid throughout the national territory (BOE No 224 of $18^{\text {th }}$ September, 2003), the European Diploma Supplement (Royal Decree 1044/2003, $1^{\text {st }}$ August, which establishes the procedure for the Supplement Universities of the European Diploma (BOE No 218 of 11 September 2003), the Qualifications Framework for the EHEA (Report 2007) and the Standards and Guidelines for Quality Assurance in the EHEA achievements were relevant to this new common space for higher education.

According to these Royal Decrees, the syllabus to achieve a degree should have 240 credits, except for the cases in which there is an opposite European directive, as the case of Medicine or Architecture. Each undergraduate degree has to

"maite.flores@usc.es, phone: +34881813502; fax: +34881813642

12th Education and Training in Optics and Photonics Conference, edited by

Manuel F. P. C. Martins Costa, Mourad Zghal, Proc. of SPIE Vol. 9289, 92891Y

(C) 2014 SPIE, OSA, IEEE, ICO · doi: 10.1117/12.2070759

Proc. of SPIE Vol. 9289 92891Y-1 
be integrated in one of the following disciplines: Arts and Humanities, Science, Health Science, Social and Legal Sciences and Engineering and Architecture. Education authorities are responsible for completing the full integration of the Spanish Education to the European higher education area. The development of the European Credit Transfer System (ECTS) has been one of the measures leading to the construction of the European Higher Education Area. This system permits that the equivalences and the recognition among degrees around Europe become easier. One of the important tasks of the Spanish education authorities is, also, to make compatible the Spanish University structure (4 years of undergraduate courses plus 1 year of master's courses) with the European model (in general 3 years of undergraduate courses plus 2 years of master's courses) ${ }^{1}$.

The Life Long Learning, within this new space for training, involves other ways of conceiving the divisions between academic life and employment. By adopting a flexible system of Degrees, understandable and comparable across all states, is intended to promote the mobility of students among different states and to have new job opportunities.

\section{EHEA IMPLEMENTATION IN PHYSICS AT THE USC}

With more than five centuries of tradition, the University of Santiago de Compostela is a historic institution that projects itself to the future and beyond its frontiers, always attentive to the different demands of society, where it stands as an important academic frame of reference and where it develops its academic, research work. Centuries of history give the University a special capacity to merge the experience, security and confidence with present and future challenge. The roots of the University of Santiago de Compostela go back to 1495. Nowadays, the USC has more than 30.000 students, around 2500 teacher and a volume of 600 international students. It has three campus, one in Lugo and two in Santiago de Compostela, and a total of 29 Degrees and 77 Master's degrees, all of them filling the rules of the EHEA .

In particular, the Physics Degree, placed in the International Campus of Excellence: "Campus Vida", in Santiago de Compostela, has a total of 240 ECTS (according the document of the "Consello Galego de Universidades" of $5^{\text {th }}$ November 2007), structured according to the following scheme: basic formation (60 ECTS), obligatory (147 ECTS), optional (27 ECTS) and the final project (6). In particular, the subject of Optics is framed in the third year of the dregree, as an obligatory course and shared in between two quaters: Optics I at the $1^{\text {st }}$ quarter with 6 ECTS and Optics II located in the $2^{\text {nd }}$ quarter, also with 6 ECTS.

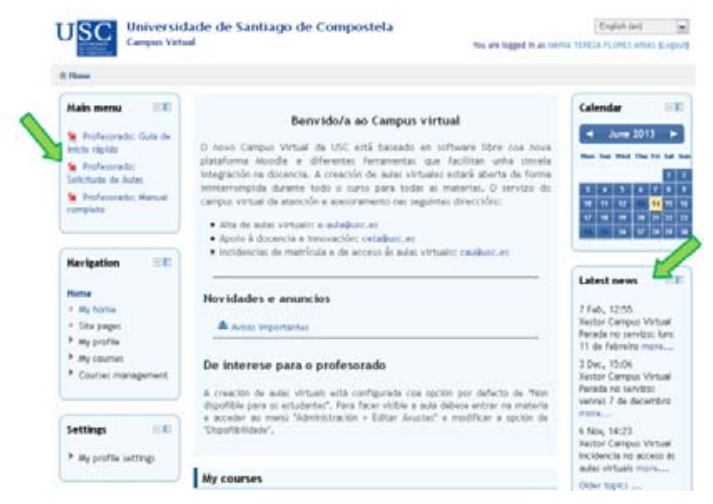

Figure 1: Screen shot of the Moodle platform used in the USC.

At the USC; 1 ECTS corresponds to 25 hours of student work, dedicated to achieving the objectives of the degree program. In this number of hours are included the hours of study, classes, seminars, assessments and so on. In particular, only 8 hours of each ECTS are devoted to attend to the teacher's explanation. Almost the total of faculty has realized that the number of hours used for explaining to the students, the theorical and practical aspects of the matter, has decreased by comparison with the older syllabus used in the USC before the EHEA implementation. This fact has 
traduced in the need to use a virtual platform that would provide educational assistance to both students and lecturers, for keeping them more connected. Throughout the years, the USC has been moving from one to other commercial virtual platform (WebCT, Blackboard...), nowadays the USC has decided to use an open access platform called Moodle.. For training the teachers for the use of the platform, USC gives specialized courses; moreover at the left-side of the main screen, there are avaliable several manuals that help the teacher and the student for using it: quick guide, extensive manual... (see figure 1)

\section{THE USE OF MOODLE PLATFORM FOR TEACHING}

The main use of the online platform is for lectures and seminars. Each teacher has a virtual space for all the courses he/she gives and can setup the visual space as he/she wants. The informatic service center of the USC is the responsible of the good behaviour of the system as weel as the confidentiality of the data. Before the lectures, the teachers upload their presentations and the class notes neccessaries for the good tracking of the course.

But the platform is also very useful for networking teachers and pupils. It has a blog that permits the teacher be connected with students by the "latest news". The system send a personal email to the students each time the teacher write a note in this section. Also there is a calendar where teacher can highlight the main date to be remembered: exercise delivery, interesting conferences, oral presentation devoted to spetial interesting topics, examination date and so on (see figure 2).

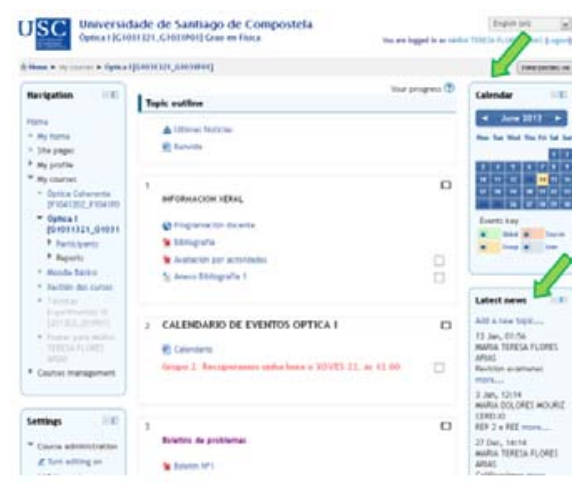

Figure 2. Screen shot of Moodle platform for the Optics I course at the USC.

Although the main use that teachers and pupils made with the platform are those related before, the platform permits also be used for examinating students. Teachers can design an exam, preferibly test, so that each pupil, whith his/her login and password, can access to his/her own examination and can solve it directly in the space designed by the platform for this end. Teachers can preset the system by weighting differently the questions proposed, in such a way, Moodle return automatically the qualification. Also for performing the continuous assessment, the pupil can deliver the proposed exercices through the platform. Teacher can define the maximum size of the documents the student can upload with the exercices and the date after which, they can not deviler. Once the teacher corrects the exercices, if he/she deemed appropriate, may reopen the delivery of exercises for each student in a particular way, resend a new version with the corrections included. Finally, each receives his/her qualification without lack of confidentiality, and how he/she has been qualified in each part of the continuous assessment (see figure 3). 


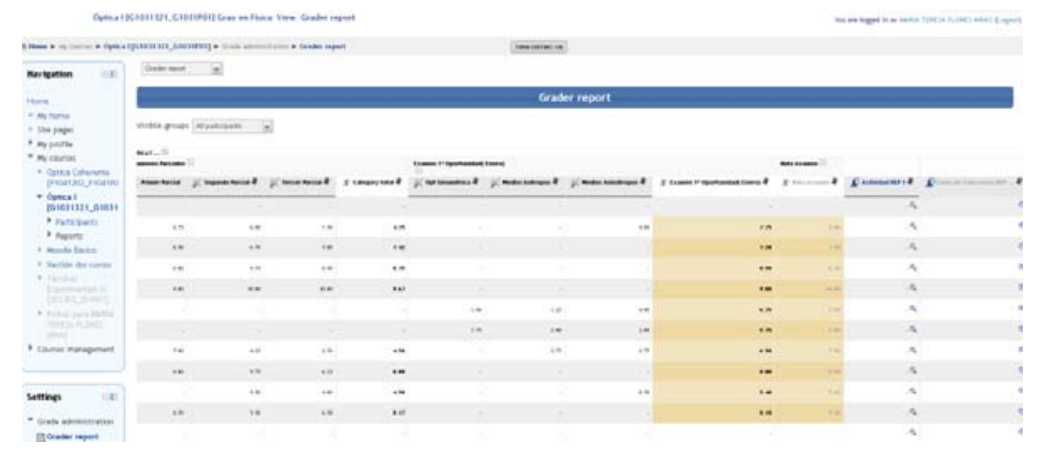

Figure 3. Grader report at the Moodle platform.

The big potential of this platform, help very much the teacher for a good performance of Optics I in the framework of the EHEA. However, sometimes teachers feel that these kind of systems, becomes a big effort for themselves but do not traduce in a good feeling for students. That is the reason because the students of the matter Optics I of the present academic year 2012-2013 were surveyed about these questions.

\section{ANALYSIS AND EVALUATION BY STUDENTS OF OPTICS I}

For knowing the opinion of the students about the use of the Moodle platform for helping the teaching, the following survey was proposed to them:

\begin{tabular}{|l|l|}
\hline How often did you use the Platform? & $\begin{array}{l}\text { a)Never } \\
\text { b) More often than not } \\
\text { c) Very often }\end{array}$ \\
\hline $\begin{array}{l}\text { Do you think that the platform has simplified } \\
\text { your work in the course Optics I? }\end{array}$ & d) Yes \\
\cline { 2 - 3 } & e) No \\
\hline $\begin{array}{l}\text { Does the platform you easy access to the } \\
\text { teacher through virtual tutorials? }\end{array}$ & f) Yes \\
\cline { 2 - 3 } & g) No \\
\hline $\begin{array}{l}\text { Do you think that the courses that rely on the } \\
\text { platform offer a big advantage over those that } \\
\text { do not? }\end{array}$ & h) Yes \\
\cline { 2 - 3 } & i) No \\
\hline $\begin{array}{l}\text { Do you value positively the method of } \\
\text { qualification through the platform in terms of } \\
\text { its speed, ease of access and confidentiality of } \\
\text { your data? }\end{array}$ & j) Yes \\
\cline { 2 - 3 } & k) No \\
\hline $\begin{array}{l}\text { Indicate your level of satisfaction with online } \\
\text { Moodle teaching system in the framework of } \\
\text { Optics I }\end{array}$ & \\
\hline
\end{tabular}

Table 1. Survey proposed to the students of Optics I

The total number of students interviewed was 24. To the question "Indicate your level of satisfaction with online Moodle teaching system in the framework of Optics I" students give a $7.8 \pm 3.5$ that means there exist a big dispersion in the responses received, but except three students a qualification equal or higher than 8 has been done. The $100 \%$ of the students answered yes to the first and second questions proposed (see table 1), that means that all of them uses very often 
the platform and consider that improves their access to the information related with the matter. A 54\% consider that the virtual tutoring sessions are not better than the personal sessions. The $87.5 \%$ of pupils value very positively the use of the platform for qualification, in terms of speed, ease of access and confidentiality of their data.

\section{CONCLUSION}

The virtual platforms are becoming each time more important to help the teaching in the new European Higher Education Area (EHEA). In particular, the use of Moodle in the subject of Optics I in the Degree of Physics of the University of Santiago de Compostela (USC) has been analyzed and evaluated by students. As summary we can say that the effort made by teachers to keep updated the platform is recognized by students. They realized that is much easier to follow a course if this platform is used. They value positively the material supplied by the Moodle system as well as the easy access to their qualifications in terms of speed and confidentiality. On the contrary, only a $46 \%$ of a total of 24 interviewed students consider that the virtual tutoring sessions are better than the personal sessions.

\section{REFERENCES}

[1] Vidal J., Lizana A., Penado A., Aso E., Lopez D., Nicolás J., Campos J. and Yzuel M.J., “Training Physics degree students in a research optics laboratory”, Proceedings, Eleventh International Topical Meeting on Education and Training in Optics and Photonics (ETOP), United Kingdom.

[2] http:// www.usc.es/es/goberno/vrodoces/eees

[3] http://www.usc.es/campusvirtual/ 